\title{
DIMENSIONS OF LEARNING ORIENTATION AND ITS IMPACT ON ORGANIZATIONAL PERFORMANCE AND COMPETITIVENESS IN SMES
}

\author{
Javier Eduardo VEGA MARTINEZ (D) 1 , \\ María del Carmen MARTINEZ SERNA (D)2* ${ }^{*}$ Neftalí PARGA MONTOYA (D)3 \\ 1, 3 Agribusiness Department, Faculty of Business Science, \\ Universidad Autónoma de Aguascalientes, Aguascalientes, México \\ ${ }^{2}$ Marketing Department, Faculty of Economic and Administrative Sciences, \\ Universidad Autónoma de Aguascalientes, Aguascalientes, México
}

Received 24 January 2019; accepted 20 November 2019

\begin{abstract}
There is evidence that indicate a positive relationship of learning orientation (LO) with organizational performance in SMEs of emerging economies. However, there are only few studies that investigate how each one of the dimensions of learning orientation (LO) contributes to variables of results such as competitiveness and organizational performance. The purpose of this study is to analyze the direct effects of each dimension of the construct (LO) with organizational performance and competitiveness, from a quantitative cross-sectional study implemented in 400 SMEs of Aguascalientes city, Mexico using SEM technique. The findings reveal that there is a direct and significant relationship between commitment to learning and shared vision with competitiveness; open-mindedness turned out to have a non-significant positive relationship with competitiveness. While the relationship of open-mindedness and commitment to learning have a positive and significant influence on organizational performance, not so shared vision that has a negative and significant influence on organizational performance. The originality of this paper, is that there is limited contributions of the relationship of LO with each dimension of competitiveness, and performance in SMEs worldwide. Among the implications found it is that the existing evidence may result different in other economies and large businesses.
\end{abstract}

Keywords: learning orientation, competitiveness, organizational performance, SMEs, commitment to learning, open-mindedness, shared-vision.

JEL Classification: M1, M10.

\section{Introduction}

The current practices of successful companies are to increase competence and knowledge skills among their members. These skills were used as a tool to promote the correct devel-

*Corresponding author. E-mail: momartin@correo.uaa.mx

Copyright (C) 2020 The Author(s). Published by VGTU Press

This is an Open Access article distributed under the terms of the Creative Commons Attribution License (http://creativecommons. org/licenses/by/4.0/), which permits unrestricted use, distribution, and reproduction in any medium, provided the original author and source are credited. 
opment of internal processes and permit to adapt to the most suitable market conditions (Ratnawati et al., 2018). Companies are characterized by being able to articulate their strategy and their employees' needs, as well as what they need to share and learn to execute the strategy, allowing them to maximize knowledge through the deployment of organizational and technological resources that will add value (Del Río \& Santisteban, 2011). The strategic orientation indicates the principles that lead the actions of the firm and create the behaviors to make sure a good performance (Hakala, 2011). When an organization prepares to compete globally, it requires skills that strengthen intelligence to develop a market, in addition to deploying best organizational learning practices (Chabowski \& Mena, 2017).

Small and medium-sized companies are permanently exposed to more competitive commercial conditions, the global economy has created situations that represent more challenges in which innovation and technological changes and know-how are integral elements of development within organizations. Nowadays, the behavior of companies is based on knowledge that must be understood by the members of the organization as an intellectual capital that needs to be adopted to solve problems of limited resources and match the needs of the market (Bature et al., 2018).

Previous researches in the field explain that it is necessary to deepen how companies should manage strategic orientations. In recent years, there has been interest in the relationship of LO with different results variables, and several studies show that there is a positive relationship (Akhtar et al., 2011). On the one hand, LO is composed of several dimensions and there are few studies that analyze the impact of each of the LO dimensions with results variables in different contexts; for example, in the study by Akhtar et al. (2011), only two dimensions have positive impact with performance. For this reason, several authors invite to develop studies to analyze how each of the dimensions of learning orientation can influence variables of results, since they apparently do not have a synergistic effect (Abbade, 2012; Gálvez et al., 2013).

Although there is plenty of literature reviewing the subject, the discussion of an ideal or optimal business performance measurement, is still inconclusive (Gupta \& Wales, 2017; Bature et al., 2018). This study analyzes two variables that measure the organizational results: competitiveness and organizational performance; both integrate the review from two perspectives, one associated with competition and the other based on objectives defined by the firm. Hence, the aim of this study is to present evidence of the relationship of LO dimensions (commitment to learning, shared vision and open mindedness) with the two results variables mentioned. The document is divided into four parts: the first, the review of the literature in terms of learning orientation, organizational performance, competitiveness, the relationship of learning orientation to organizational performance in SMEs and the relationship of learning orientation with the competitiveness of SMEs; the second part consists of methodological aspects; The third part is the results of the study based on the application of the corresponding statistical techniques and finally the discussion and conclusions. 


\section{Literature review}

\subsection{Learning orientation}

The present investigation adopts the resource-based theory and capabilities (Wernerfelt, 1984) since it has a primordial role in the development of company competitiveness. This approach visualizes companies as a system of structures that generate profitability (Barney et al., 2001), not because of their strategic investments, but rather to base their performance on resources and internal capabilities that strengthen the firm competitive advantages (Yazfanfar, 2013). LO is a construct that acknowledges the attitude of managers to consider learning as a key resource for the organization, also understands the need to unlearn obsolete knowledge, to eliminate old mental models, and welcome new learning (Bontis et al., 2002). "Learning is a crucial process in achieving an adequate crisis response, a proper return to normality" (Broekema et al., 2019, p. 200). The LO is considered as a resource and organizational capability that supports companies to develop their competitiveness and organizational performance.

According to Argyris (1976), learning is one of the most important resources to develop the ability to make decisions that correspond to the effectiveness of the company. Not consolidating learning means that errors are not detected or corrected, which cause an organization to be inefficient due to the lack of information shared or developed by the same members of the firm; therefore, the problems increase due to the ambiguity that persists due to the sub structured sequence of learning practices.

Sinkula et al. (1997), defined the LO as the set of organizational values that proactively influence the knowledge generation, in order to interpret, evaluate, accept or reject the information received by the company. It causes a predisposition of individuals to have routines related to learning commitment, open-mindedness and shared vision.

On the one hand, Baker and Sinkula (1999) related the scope of the LO as a capacity that improves the company's offer, since it maximizes the correct interpretation of the links that conform the value chain (customers, distribution channels, competitors, etc.) to provide solutions according to the orientation of the current market (Ellinger et al., 2015; Iyer et al., 2019). For Baba (2015), LO is a collective capacity derived from the cognitive and experiential process and involves the acquisition, exchange and use of knowledge. In the same way, Liao et al. (2017) defined the LO as an organizational process to improve individual knowledge by transforming it into part of the knowledge system of the organization, in an organized and understandable way as well as the commitment to learning, open-mindedness and shared vision (Lita \& Faisal, 2018).

Different theoretical models have been proposed for the study of learning, their contribution to organizations has been done through a process designed for the development of internal knowledge, for which it has been recognized as a strategic orientation within the firm (Dutta et al., 2016). Generative or double-loop learning according to Argyris and Schön (1978) is identified in the literature, in which the mental models and the theories in use are questioned. Doing so, produces radical or incremental changes presented at different levels: individual, group and organizational level (Baker \& Sinkula, 1999; Crossan et al., 1999); and 
associated four processes such as the acquisition, distribution, interpretation and memory of information (Huber, 1991; Crossan et al., 1999).

Regarding the LO structure, Sinkula et al. (1997) point out three dimensions: commitment to learning, open mindedness and shared vision. Others measure LO with four dimensions: commitment to learning, open-mindedness, shared vision and knowledge exchange (Hurley \& Hult, 1998); and Cardona and Calderón (2006) consider the LO formed with the dimensions of commitment to learning, ability to unlearn what has been learned, openness and experimentation.

In the context of this study, three organizational values that predispose the organization to learn are considered: commitment to learning, an open-mindedness and a shared vision. Commitment to learning is the degree to which an organization values and promotes learning, it plays a key role in promoting the culture of sharing knowledge within the organization (Sinkula et al., 1997), considering this as a long-term investment that it becomes a survival factor (Calantone et al., 2002). A shared vision welcomes the individual efforts towards the same direction in order to share information that could influence in a positive way the knowledge base of a firm, a company must continuously renew operational systems routines, and capabilities according to the dynamics market's needs (García et al., 2011; Bature et al., 2018). Open-mindedness details the policies of the company, the basis or normativity that have to do with the openness to new ideas and/or initiatives that collaborators promote (Bature et al., 2018).

\subsection{Organizational performance}

Organizational performance is considered as a product of the interactions from different parts or units within an organization. Stankard (2002) refers to the general well-being of the company expressed in terms of results from the efforts to achieve employee's expectations in regards to the objectives (Agwu, 2018). Organizational performance is measured through financial, operational and personnel indicators with challenging objectives but reasonable (Dávila \& Elvira, 2010); it also relate it to elements that have to do with the company survival: mission, vision and objectives (Gálvez \& García, 2011).

In the literature, there is a perspective that states that organizational performance is a multidimensional concept; one of its purposes is to measure the organization, that is, if they were able to meet the objectives proposed by investors (Richard et al., 2009). It is also a way to attract new investors (Shad et al., 2019). For Venkatraman and Ramanujam (1986), consists of three "spheres" that complement each other. The first is the dimension of the effectiveness of the organization, related to social and economic objective. The second corresponds to the operational dimension, besides of financial indicators, considers aspects of marketing, new products, market share, and productivity. The third sphere is the financial dimension that is the dominant model of strategic empirical research, this dimension considers ROI, increase in sales, profitability, among others.

In a broader context, different methods and tools have been designed to measure performance in companies in subjective and objective criteria (Gálvez \& García, 2011), objective such as the balanced scorecard, that is within the context of measuring businesses perfor- 
mance that integrate indicators, and financial, non-financial (Rehman et al., 2019) and operational perspectives (Parra, 2006). According to Dragnić (2014), when objective indicators are taken into account, the credibility of research results increases, subjective tools can be related to perceptions or points of view (Parra, 2006), effectiveness and efficiency indicators (compliance of expectations, plans) and also subjectively when compared with the competitors (Dragnić, 2014).

In accordance with Chenhall and Langfield-Smith (2007) and their observations, organizational performance measures five areas: strategy, operations management, human resources, marketing and finance (cited by Kerfai \& Ghadhab, 2016). In view of different perspectives and different ways of measuring it, the study on the subject recognizes the significance of relating performance measures from a theoretical perspective and admit a construct that includes strategic advantage (Richard et al., 2009; de Brito \& de Oliveira, 2016). Previous studies recognize the existence of different approaches and metrics, most of the authors refer to the importance of linking performance measures with a theoretical approach and even with a greater construct (Combs et al., 2005; Richard et al., 2009).

\subsection{Competitiveness}

Competitiveness, at the international level, has been applied as reference to compare and evaluate the economic and financial performance of countries (World Economic Forum, 2018). Furthermore, the analysis of business competitiveness has been evaluated in the field of resources and capabilities that create unique combinations with impact on organizational efficiency (Ratnawati et al., 2018). Camisón and Puig (2014) argued that, in this organizational approach, dynamic capabilities are a strategic value that adapts to new competitive advantages, therefore, it is necessary to acquire resources, integrate them and recombine them to develop strategies that create value for the firm (Anning-Dorson, 2016).

The competitiveness concept from a business approach is built on elements that are linked to the activities of the company such as decision-making innovation, management and human resources. The indicators that measure competitiveness are related to profitability, market share, technological innovation, costs, quality, to name a few (Arévalo \& Sosa, 2017). In addition, business competitiveness (Rubio, 2004, p. 15) is defined as "the ability to compete with other companies, achieve a favorable competitive position, which allows to obtaining a performance superior to that of the competitors". For Rubio and Aragón (2006), the key to competitiveness in SMEs are the resources identified as critical: technological resources, innovation, commercial resources, quality, human resources, managerial skills and culture.

Saavedra et al. (2013) refer to competitiveness according to Lall et al. (2005), who point out that companies are competing to enter new markets, expand their market share. Competitiveness or profitability is measured by the level of participation in the market, to create a competitive strategy and achieve a better performance (Aragón \& Sánchez, 2003). "Obtaining a competitive advantage depends on the ability to capture rents in a sustained manner" (Giménez et al., 2019, p. 3).

According to Camisón (1997), competitive success is proved by the capacity of a company through an efficient management of the development of strategies. A combination of internal 
and external resources available in the organization, allow it to compete in market. It is necessary to have adequate financial management, plan carefully short-term actions, implement a cost control system, establish annual budgets and seek its own sources of financing (Rubio \& Aragón, 2006).

Additionally, Buckley, Pass and Prescott (1988) argued that the lower are the costs generated by the company, more competitive this will be. In addition, an organization can reduce its costs efficiently, but at the same time, it may not generate sufficient benefits to be considered competitive. Technology is also another indicator of competitiveness, Buckley et al. (1988) noted that organizations that invest heavily in research and technology are more likely to be competitive. However, it is necessary to pay attention to the fact that this technology will aim to satisfy customer needs.

In the same way, Pérez, Gutiérrez and Agudo (2019) found in their study that the affective Commitment has a positive and significant influence. In this research, the competitiveness construct is based on the scale of Maldonado (2008), an adjustment with criteria indicated by Buckley et al. (1988) which considers three factors: financial results, costs reduction and technology; the dimensions were evaluated by comparing the organizational results with the competitors.

\subsection{The relationship of learning orientation with organizational performance in SMEs}

According to Cardona and Calderón (2006), contrasting results have been found in the study of the relation of learning orientation with organizational performance, in other words, there are authors who link LO with positive results in organizations and performance improvement (Slater \& Narver, 1995; Sawaean \& Ali, 2020). On the other hand, there are those who say that learning does not necessarily improve performance or there is no positive relationship between them (Crossan et al., 1999; Jerez, 2001).

In an empirical study, applied to Spanish companies with the highest turnover in the following sectors: agro-fishing, industry, construction and services; it was demonstrated that adaptive learning and generative learning result in improvements in innovation and in organizational performance, with generative learning being the most influential that leads to the creation of more competitive strategies (García et al., 2011). Similarly, Araiza et al. (2014) found that learning is related to perceived operational performance in companies, as well as the three components of organizational learning: learning orientation, shared knowledge, knowledge and retention recovery, influence on organizations performance (Cardona \& Calderón, 2006).

Another evidence is the study conducted in 123 SMEs of Rio Grande do Sul by Abbade (2012), to prove the influence of LO with performance. It was found that only the dimension of open-mindedness has a positive and significant impact, the other two dimensions, learning commitment and shared vision, presented positive influence but not significant. These results contradict some theoretical cases, challenging the systemic thinking of Senge (1990), and the position of Sinkula et al. (1997) since the commitment to learning and shared vision does not influence significantly with organizational performance. The authors invite to develop future studies analyzing how each of the dimensions of LO can influence performance. 
On the other hand, Perin et al. (2016) suggest developing an open-mindedness position in Brazilian companies in the industrial sector, due to its positive indirect effect on the performance of the company. The results of this study help to understand the nature and function of the open mindedness in the implementation of internal and external social networks and how they could be used to improve financial performance. In a study conducted in Taiwan, Yang and Huang (2018) conclude that companies in the supply chain could reinforce the effect on the performance of the company through a shared vision.

On the contrary, Gálvez et al. (2013), found a significant positive relationship in an empirical research on the relationship of LO with organizational performance in 403 Colombian SMEs. The practices applied by the organization in the case of commitment to the learning, unlearning, openness and experimentation, contribute in a very important way. Hence, the organization obtains improvements in the quality of its products, coordination of internal processes, customer satisfaction, the ability to adapt to changing market, brand image of the company and its products. On the other hand, Hooi and Ngui (2014) and Potnuru et al. (2019) found that the learning capacity of small and medium enterprises mediates the effect of human resource practices on the performance. Other authors point out that "the organizational learning constitutes a cumulative set of knowledge over time, however, in small enterprises with up to 49 employees, there might not have structured processes of organizational learning, and therefore they propose that the organizational learning will have a negative and significant relationship with the organizational performance, they confirm the hypothesis (Vasconcelos et al., 2016).

LO has been considered as a variable that supports or moderates the relationship between entrepreneurial orientation (EO) and market orientation (MO) with performance, that is, as part of a combination with diverse strategic orientations to achieve a better performance (Dutta et al., 2016). The adoption of LO can lead to performance as team members can learn about the organizational environment, being the main determinant in the performance of the business (Real et al., 2014; Lita \& Faisal, 2018), since they accept the criticisms and suggestions of the customers (Mahmoud et al., 2016).

The empirical review of the relationship of LO and organizational performance, have supported this positive influence (Lita \& Faisal, 2018; Hussein et al., 2014; Mahmoud \& Yusif, 2012). Bature et al. (2018) notes that commitment to learning, shared vision and open-mindedness, clearly show how small and medium enterprises can create and use skills, knowledge and technically they know how to extend strong capabilities that result in superior performance. Likewise, Garrido and Camarero (2010), found that LO has a significant influence on performance, specifically it was found that it has improved financial and social performance in a study applied to 386 museums in Spain, France and England.

For the previously mentioned, the following hypotheses are proposed:

- H1. Commitment to learning has a direct and positive influence on SMEs organizational performance

- H2. Open-mindedness has a direct and positive influence on SMEs organizational performance

- H3. Shared vision has a direct and positive influence on SMEs organizational performance 


\subsection{The relationship of learning orientation with SMEs' competitiveness}

The key to achieve competitive advantages, is the ability to learn (Sinkula et al., 1997), the LO involves individuals throughout the organization to create and use knowledge to achieve a competitive advantage (Calantone et al., 2002). Salunke et al. (2019) demonstrates the importance of strategic knowledge learning to have the competitive advantage; a high LO can provide competitive advantages for the survival and growth of the organization. According to several authors, competitiveness is subject to opportunities exploited in the market, team members must be motivated to learn, develop and share their skills, as well as their learning habits with others (Von Krogh et al., 2012).

Learning orientation has been considered in different studies as a variable that indirectly affects the competitiveness of companies, since it is represented as a factor that has effects on variables such as innovation, market orientation and intellectual capital, that directly have an impact on competitiveness (Ahmedova, 2015; Allameh \& Khalilakbar, 2018).

LO also uses organizational knowledge to promote competitiveness, as it guides the ideals of organizational culture to enable companies to the beliefs, practices, principles and traditions on how the organization should operate based on the understanding of business competences in response to changes in the markets (Bature et al., 2018). The results by Iyer et al. (2019), indicate the importance of a learning culture to exploit resources to build capacities that respond to the market and provide them with a competitive advantage.

With a learning orientation, managers play a fundamental role in building the right environment. The commitment to learning must be seen, both by managers and employees, as a value that generates competitive advantages in the organization, a shared vision explains us that managers are responsible for the LO in their organization. Finally, it is important to highlight that in an open-mindedness culture, employees see themselves as partners, they communicate freely and managers know how to interpret it (Lita \& Faisal, 2018). LO creates conditions of improving organizational competitiveness, due to it increased the adaptability of the company, allowing the individuals to take advantage of the opportunities detected with cognitive mechanisms based on learning (An et al., 2017; Mahmoud et al., 2016; Wolff et al., 2015).

Hussein et al. (2014) suggest that the LO helps to improve the competitive advantage and change the capacity of response of the organization, which later attract interest in developing organizations that promote and encourage learning; it is associated with the prompt delivery of the product, cost improvement, quality and confidence in the performance (Tajeddini, 2016).

In the case of SMEs, Ratnawati et al. (2018) has mentioned they resort to LO strategies to empower their employees through the formation of new capacities, processes and use of information to have more success in the daily activities and have direct influence on the competitiveness of the firm. The implementation of best practices in SMEs is in particular a process of creating, acquiring, and retaining, sharing and applying knowledge to reduce costs, resources or inputs in order to achieve better competitiveness. Although due to the size of the same they resort regularly to conventional training and training strategies without having more than a limited projection of their spectrum (Ahmedova, 2015). 
Therefore, the following hypotheses are developed to examine a relationship between LO dimensions and competitiveness:

- H4. Commitment to learning has a direct and positive influence on SMEs competitiveness

- H5. Open-mindedness has a direct and positive influence on SMEs competitiveness

- H6. Shared vision has a direct and positive influence on SMEs competitiveness

\section{Methodology}

\subsection{Research design}

The database for this quantitative research was collected through an interview survey instrument in Aguascalientes, Mexico. It is a designed transversal study, sampling is nonprobabilistic casual, and the key respondent was the owner managers and/or high-level executives of the SMEs who are regarded as the main source of information because they are directly responsible for planning and management of the firm. Aguascalientes city recorded $8.1 \%$ economic growth over the previous year in the third quarter of 2016 (Secretaría de Economía, 2016) higher than the national growth, according to the Mexican Institute for Competitiveness (IMCO, 2016), Aguascalientes is the second most competitive city of Mexico, for this reason, it was selected to carry out this study. The list of companies was obtained from the database of the National Statistics Board of Economic Units (DENUE) (INEGI, 2016a) and according to this information; the size population is 5,658 companies. The stratification of the companies according to the number of employees (INEGI, 2016b), micro enterprises ( 1 to 10 employees), small enterprises (11 to 50 employees), mediumsized enterprises (51 to 250 employees). After the listing, the sample size was calculated resulting in 360 companies with a confidence percentage of $95 \%$ and an error of $5 \%$. A total of 650 SMEs (a range from 5 to 250 employees), were randomly selected from the DENUE (INEGI, 2016a) directory.

The key respondents were contacted by telephone to invite them to participate in the study. After that, with the SME owners who agreed to participate in the study, an approach was made to collect the information from the questionnaire personally, the acceptance rate was $67 \%$, that is, 400 companies accessed to answer the instrument of data collection.

Companies contacted are from the following sectors: $32 \%$ in the commerce and services sector (commerce 16.8\%, services 15.2\%); 68\% developed activities of the industrial (sector textile $8.8 \%$, furniture $8.5 \%$, agribusiness $20.2 \%$, metalworking $12.5 \%$, construction $9 \%$ and other industries $9 \%$ ).

To sum up the important data collected from the key respondents indicate that $84.3 \%$ of SMEs management is led by men, $74.3 \%$ of managers are aged 30 to 44 years and $17.8 \%$ among 18 to 29 years-olds; regarding the level of education, $55.3 \%$ have undergraduate or engineering studies, $3.6 \%$ have a master or $\mathrm{PhD}$. The $34.7 \%$ of the companies contacted are microenterprises, $52.5 \%$ small enterprises and $12.80 \%$ medium-sized enterprises, the majority control is in charge of a family member in $67 \%$ of the cases as well as $88.88 \%$ the managerial positions are formed by a family member. Finally, $63.75 \%$ of the companies are from one to fifteen years in business, $30.5 \%$ from 16 to 35 and $5.75 \%$ from 36 and up. 
The questionnaire that was used for the collection of information was composed of three sections, the first one contained the data of the key respondents, the second the data of the companies that agreed to participate and the third the items of the scales for the measurement of the main constructs; The competitiveness scale was composed of three factors with a total of 12 items, the organizational learning scale with three factors with a total of 15 items and the organizational performance scale with 6 items giving a total of 33 items for the three constructs.

\subsection{Measurement of variables}

For the measurements of the constructs, theory and previous studies were reviewed to select the scales that were used to measure LO, competitiveness and organizational performance, the key constructs are latent, all constructs are measured with items on a five-point Likert scale rating from 1 to 5 . Later, data are submitted to a confirmatory factorial analysis to verify the validity of the constructs, in which 6 variables were eliminated leaving 27 variables that were finally used to carry out the study.

The scale of Sinkula et al. (1997) was adapted to measure LO, which considers three factors: The first factor commitment to learning, it was measured the degree to which an organization values and promotes learning, and the degree to which the organization promotes the culture of sharing knowledge which was integrated by three ítems. The second dimension shared vision, it was measured the degree to which the organization promotes all the individual efforts toward the same direction in order to share information that could impact on a positive way the knowledge base of a firm which was integrated by four ítems. The third dimension of open-mindedness, it was measured the degree to which the company details the policies of the company, the basis or normativity that have to do with the openness to new ideas and / or initiatives that collaborators promote which was integrated by three ítems. The original scale has been adapted and translated into Spanish in several studies with good validity and reliability (Martínez, 2004). A total of 10 items constituted the scale of learning orientation.

In the case of measuring the competitiveness construct, the absence of objective measures, subjective measurements were used and constructed from indicators with the perception of the manager or owner. This is commonly used in research when data is not accessible; this is because there is resistance on the part of companies in giving "hard" performance data of their companies (Llonch et al., 2007). These scales request to indicate the perception on the part of the owner or high executive regarding the results of his company. Before the debate of the pertinence of the use of these scales, investigations have been made in the that verify the difference between the measurement of results with subjective and objective scales, there being evidence that the results are highly correlated (Dess \& Robinson, 1984; Pearce et al., 1987; Slater \& Narver, 1994; Llonch et al., 2007). Due to this consistency of previous studies, these scales have been widely accepted in the academic community so its use in measurements of scientific works is considered pertinent (Geringer \& Herbert, 1991 cited by Hooi \& Ngui, 2014).

The competitiveness scale was formed by three factors, each of them is estimated by a series of indicators or items. The first factor is that of financial performance that was measured 
with three items in which the key respondents was asked to indicate the results compared to the average of his competition in three different items which were sales, return on investment and profits. The second factor of purchasing costs was measured with five items in which the key respondents were asked about their results compared to the competition in the last three years in five items: coordination costs with suppliers, costs of orders with suppliers, transport costs with suppliers, delivery costs of products with suppliers, production costs. The third Technology factor was measured with four items in which the key respondent was asked about its situation in relation to the competition in the last three years in four aspects: Development of technology, development of products or services, development of processes and / or services and development of information technology. In total, the competitiveness scale was made up of 12 items. The scale was an adaptation of Maldonado (2008) y Maldonado et al., (2012) with criteria indicated by indicated by Buckley et al. (1988). Regarding the dimensions of Technology and reduction of costs in purchases and some items of profitability, in this scale the owner was asked about their perception in the results in the company in relation to the competition in the past three years. They were directed to indicate their response on a scale of -1 - much lower to -5 - much higher, this scale is conserved with the same number of items given its good measures of Reliability and validity in previous studies.

In order to measure organizational performance, it was used some of the criteria implemented in the work of Llonch et al. (2007). This first order construct consisted in five items in which owners or managers were asked to indicate on a scale of - 1 - very low to -5 - very high. What had been the evolution of the following aspects in the last two years in relation to the objectives of the company: level of return on investment (ROI), level of benefits, increase in sales and overall results. In addition to the criteria of Llonch et al. (2007) customer satisfaction was considered as additional items as well as employee satisfaction and the organizational results of the last two periods of the firm. In total there were 3 constructs composed of 7 factors and 27 variables that made up the same study that can be seen in Table 1.

\subsection{Data analysis}

A SEM approach (Structural Equation Modeling) has been selected to carry out to analyze all the variables of the model simultaneously (Fornell, 1985). According to Medrano and Muñoz-Navarro (2017) structural equation models or Structural Equation Modeling (SEM) "are considered among the most powerful tools for the study of causal relationships in nonexperimental data. They are a combination of factor analysis and multiple regression and are composed of two components: the measurement model and the structural model" (p. 220). For Byrne (2006) is a statistical methodology that uses structural theory in a given phenomenon. Data has been applied to SPSS, statistical software for processing questionnaires and AMOS version 23 (Analysis of moment structures, Arbuckle, 2003) which permit us to use a graphical interface to specify the hypothesis between the variables in question.

The six stages that the theory marks to carry out the SEM were followed: 1) Specification of the model: the theory was revised and the relations of the proposed model was established. 2) Identification of the model: The number of degrees of freedom was verified, being the gl greater than zero, so the model was over identified. 3) Estimation of the model. 4) Evaluation of the model: the values of the parameters that maximize the equality between the covari- 
ances of the proposed model and those analyzed with the sample were obtained. 5) Evaluation of the model: the adjustment of the model was assessed through absolute goodness-of-fit statistics, relative adjustment statistics and the average square root of the approximation error. 6) Re-specification of the model: Adjustment indexes were verified and the residuals analyzed and it was respecified to improve the total fit of the model.

\subsection{Measurement of the model}

Following the same approach of different authors, SEM analysis was carried out, taking into consideration the recommendation of Anderson and Gerbing (1988) of two steps: first the CFA analysis and later, SEM analysis to verify the model's fit and the validation of the hypotheses respectively. As it is developed in practice, the reliability of the constructs that structure the LO study, competitiveness and organizational performance were also verified, in order to subsequently obtained the validity (content, convergent and discriminant) of the constructs.

The validity of the measurements was verified through Cronbach's Alpha, which assumes that the factors measure the same construct and are strongly correlated with each other. According to Peterson (1994), the recommended level must be higher than 0.7, the three scales reach the level indicated since it ranged from 0.796 to 0.921 , and the results from the composite reliability index (Bagozzi \& Yi, 1988) ranged from 0.814 to 0.827 , which corroborates the reliability of the measurement scales.

As a next step, the group of variables was subjected to a confirmatory factorial analysis (CFA). The standardized factor loads and the adjustment indices are presented in Table 1. The adjustment indices used were the Normed Fit Index (NFI), the Incremental Fit Index (IFI), the Comparative Fit Index (CFI) and the Root Mean Square Error of Approximation (RMSEA) (Byrne, 1989; Bentler, 1990). According to the theory, values close to one indicate a good fit (Byrne, 1998), the Root Mean Square Error of Approximation (RMSEA) index was also verified, which should be between the values of 0.05 and 0.08 (Jöreskog \& Sörbom, 1986; Hair et al., 1995). The results of the confirmatory factor analysis indicated a good fit (SB / $\mathrm{df}=1.824$, IFI $=0.963, \mathrm{CFI}=0.963, \mathrm{NFI}=0.922$, RMSEA $=0.045)$. All items of the factors were significant and the loads of the standardized factors exceed 0.7 (Bagozzi \& Yi, 1988), the index of variance extracted must be greater than 0.50 (Fornell \& Larcker, 1981), in this case the values range from 0.532 to 0.726 .

Table 1. Reliability and convergent validity of the measurement scale (source: Authors (2018))

\begin{tabular}{|c|l|c|c|c|c|c|c|c|}
\hline \multirow{2}{*}{ Factor } & \multicolumn{1}{|c|}{ Item } & \multicolumn{2}{|c|}{$\begin{array}{c}\text { Factor } \\
\text { loading }\end{array}$} & $\begin{array}{c}\text { Loading } \\
\text { average }\end{array}$ & $\begin{array}{c}\text { Cronbach } \\
\alpha\end{array}$ & CRI & AVE & VIF \\
\hline \multirow{2}{*}{$\begin{array}{l}\text { Commitmen } \\
\text { to learning }\end{array}$} & COA2 & 0.710 & & 0.820 & 0.888 & 0.860 & 0.676 & 1.872 \\
\cline { 2 - 10 } & COA3 & 0.955 & $* * *$ & & & & & 3.247 \\
\cline { 2 - 10 } & COA4 & 0.782 & $* * *$ & & & & & 2.303 \\
\hline \multirow{5}{*}{ Shared vision } & VIC1 & 0.760 & & 0.740 & 0.850 & 0.827 & 0.545 & 3.072 \\
\cline { 2 - 9 } & VIC2 & 0.720 & $* * *$ & & & & & 3.353 \\
\cline { 2 - 9 } & VIC3 & 0.760 & $* * *$ & & & & & 2.028 \\
\cline { 2 - 9 } & VIC5 & 0.710 & $* * *$ & & & & & 1.515 \\
\hline
\end{tabular}


End of Table 1

\begin{tabular}{|c|c|c|c|c|c|c|c|c|}
\hline Factor & Item & \multicolumn{2}{|c|}{$\begin{array}{l}\text { Factor } \\
\text { loading }\end{array}$} & $\begin{array}{l}\text { Loading } \\
\text { average }\end{array}$ & $\begin{array}{c}\text { Cronbach } \\
\alpha\end{array}$ & CRI & AVE & VIF \\
\hline \multirow{3}{*}{$\begin{array}{l}\text { Open- } \\
\text { mindedness }\end{array}$} & MEA1 & 0.920 & & 0.770 & 0.824 & 0.814 & 0.598 & 2.055 \\
\hline & MEA2 & 0.720 & $* * *$ & & & & & 2.050 \\
\hline & MEA3 & 0.650 & $* * *$ & & & & & 1.671 \\
\hline \multirow{3}{*}{$\begin{array}{l}\text { Finance } \\
\text { performance }\end{array}$} & FP1 & 0.890 & & 0.850 & 0.884 & 0.888 & 0.726 & 2.940 \\
\hline & FP2 & 0.880 & $* * *$ & & & & & 2.988 \\
\hline & FP3 & 0.780 & $* * *$ & & & & & 2.118 \\
\hline \multirow{5}{*}{ Costs } & PC1 & 0.980 & & 0.790 & 0.796 & 0.898 & 0.642 & 5.038 \\
\hline & PC2 & 0.850 & $* * *$ & & & & & 4.782 \\
\hline & PC3 & 0.710 & $* * *$ & & & & & 3.667 \\
\hline & PC4 & 0.700 & $* * *$ & & & & & 3.080 \\
\hline & PC6 & 0.730 & $* * *$ & & & & & 2.149 \\
\hline \multirow{4}{*}{ Technology } & TE1 & 0.900 & & 0.820 & 0.921 & 0.889 & 0.669 & 2.955 \\
\hline & TE2 & 0.840 & $* * *$ & & & & & 3.308 \\
\hline & TE3 & 0.790 & $* * *$ & & & & & 2.731 \\
\hline & TE6 & 0.740 & $* * *$ & & & & & 1.944 \\
\hline \multirow{5}{*}{$\begin{array}{l}\text { Organi- } \\
\text { zational } \\
\text { performance }\end{array}$} & PE1 & 0.580 & & 0.710 & 0.867 & 0.844 & 0.532 & 1.532 \\
\hline & PE3 & 0.530 & $* * *$ & & & & & 2.011 \\
\hline & PE4 & 0.620 & $* * *$ & & & & & 3.189 \\
\hline & PE5 & 0.880 & $* * *$ & & & & & 4.931 \\
\hline & PE6 & 0.940 & $* * *$ & & & & & 3.759 \\
\hline
\end{tabular}

Notes: Model fit measures for the general model: $\mathrm{Chi}^{2} / \mathrm{df}=1.824(\mathrm{p}=0.000)$; RMSEA $=0.045$; IFI $=$ 0.963; CFI $=0.963$; NFI $=0.922$; Significance values: ${ }^{*}=\mathrm{p}<0.05 ;{ }^{* *}=\mathrm{p}<0.01 ;{ }^{* *}=\mathrm{p}<0.001$.

The discriminant validity of the measurement scales is confirmed through the Average Variance Extracted (AVE), in Table 2 the diagonal formed by the AVE of each construct is observed, the results that are below the diagonal are the correlation to the square of each pair of constructs. The value of the square of the correlations must be less than its AVE (Fornell \& Larcker, 1981). This demonstrates that the measurement scales used in this research have discriminant validity (see Table 2).

Table 2. Discriminant validity of the measurement scale (source: Authors (2018))

\begin{tabular}{|l|c|c|c|c|c|c|c|}
\hline & $\begin{array}{c}\text { Commit- } \\
\text { ment to } \\
\text { learning }\end{array}$ & $\begin{array}{c}\text { Shared } \\
\text { vision }\end{array}$ & $\begin{array}{c}\text { Open- } \\
\text { minded- } \\
\text { ness }\end{array}$ & $\begin{array}{c}\text { Finance } \\
\text { perfor- } \\
\text { mance }\end{array}$ & $\begin{array}{c}\text { Costs } \\
\text { reduction }\end{array}$ & $\begin{array}{c}\text { Techno- } \\
\text { logy }\end{array}$ & $\begin{array}{c}\text { Organi- } \\
\text { zational } \\
\text { perfor- } \\
\text { mance }\end{array}$ \\
\hline $\begin{array}{l}\text { Commit- } \\
\text { ment to } \\
\text { learning }\end{array}$ & 0.676 & & & & & & \\
\hline
\end{tabular}


End of Table 2

\begin{tabular}{|c|c|c|c|c|c|c|c|}
\hline & $\begin{array}{c}\text { Commit- } \\
\text { ment to } \\
\text { learning }\end{array}$ & $\begin{array}{l}\text { Shared } \\
\text { vision }\end{array}$ & $\begin{array}{l}\text { Open- } \\
\text { minded- } \\
\text { ness }\end{array}$ & $\begin{array}{l}\text { Finance } \\
\text { perfor- } \\
\text { mance }\end{array}$ & $\begin{array}{l}\text { Costs } \\
\text { reduction }\end{array}$ & $\begin{array}{c}\text { Techno- } \\
\text { logy }\end{array}$ & $\begin{array}{l}\text { Organi- } \\
\text { zational } \\
\text { perfor- } \\
\text { mance }\end{array}$ \\
\hline $\begin{array}{l}\text { Shared } \\
\text { vision }\end{array}$ & 0.268 & 0.545 & & & & & \\
\hline $\begin{array}{l}\text { Open- } \\
\text { minded- } \\
\text { ness }\end{array}$ & 0.112 & 0.404 & 0.598 & & & & \\
\hline $\begin{array}{l}\text { Finance } \\
\text { perfor- } \\
\text { mance }\end{array}$ & 0.110 & 0.043 & 0.076 & 0.726 & & & \\
\hline $\begin{array}{l}\text { Costs } \\
\text { reduction }\end{array}$ & 0.008 & 0.042 & 0.010 & 0.040 & 0.642 & & \\
\hline $\begin{array}{l}\text { Techno- } \\
\text { logy }\end{array}$ & 0.031 & 0.051 & 0.041 & 0.008 & 0.071 & 0.669 & \\
\hline $\begin{array}{l}\text { Organi- } \\
\text { zational } \\
\text { perfor- } \\
\text { mance }\end{array}$ & 0.090 & 0.043 & 0.128 & 0.035 & 0.009 & 0.080 & 0.463 \\
\hline
\end{tabular}

After all analysis and checking the adjustment indices, it is confirmed that the measurement model presents an acceptable adjustment. Therefore, it was proceed to develop the structural model using the confirmatory modeling method through AMOS (version 23.0).

\section{Results}

The descriptive results of the analyzed variables are presented (see Table 3). It was observed that the variable with the highest score was Commitment to learning, which obtained 3.62 points Likert (Important). In the case of the lowest variable was Technology, having an average of 2.45 Likert points (low), in addition to being the variable with the greatest variability, which indicates that the analyzed companies have different technological conditions, probably due to the size and business sectors of these. In the same way, on the one hand, the correlations between the LO dimensions and the Competitiveness dimensions are observed, positive correlations were statistically significant at $1 \%$ in a range of $r=0.15$ (Open mindedness and Technology) $r=0.34$ (Shared vision and Finance performance). On the other hand, the correlations of LO with Organizational performance are also shown, in which there are also significant positive correlations at $1 \%$ that have a range of $r=0.19$ (Shared vision and Organizational Performance) $r=0.34$ (Open mindedness and Organizational Performance). Previous studies have obtained similar results in the effect of LO on competitiveness (Hayati \& Rukhviyanti, 2016; Ratnawati et al., 2018; Vargas, 2015). Especially in the performance of technology (Allameh \& Khalilakbar, 2018; Anning-Dorson, 2016) and organizational performance (Beneke et al., 2016; Hayati \& Rukhviyanti, 2016; Homaid et al., 2018; Kasim et al., 2018). So, the consistency of results, throw important findings on the Open mindedness dimension. 
Table 3. Descriptive analysis and bivariate correlations (source: Authors (2018))

\begin{tabular}{|c|c|c|c|c|c|c|c|c|c|c|}
\hline & & Mean & SD & 1 & 2 & 3 & 4 & 5 & 6 & 7 \\
\hline 1 & $\begin{array}{l}\text { Commitment to } \\
\text { learning }\end{array}$ & 3.62 & 1.12 & 1 & & & & & & \\
\hline 2 & Shared vision & 3.44 & 1.03 & $0.46^{\star * *}$ & 1 & & & & & \\
\hline 3 & Open mindedness & 3.32 & 1.07 & $0.31^{\star * *}$ & $0.50^{\star * \star}$ & 1 & & & & \\
\hline 4 & Finance performance & 3.51 & 0.97 & $0.33^{\star * *}$ & $0.34^{\star \star \star}$ & $0.26^{\star \star *}$ & 1 & & & \\
\hline 5 & Cost reduction & 2.94 & 1.06 & $0.13^{\star * *}$ & $0.16^{\star \star \star}$ & $0.11^{\star *}$ & $0.20^{\star \star \star}$ & 1 & & \\
\hline 6 & Technology & 2.45 & 1.23 & $0.19^{* * *}$ & $0.18^{\star \star \star}$ & $0.15^{\star \star \star}$ & 0.07 & $0.23^{* * *}$ & 1 & \\
\hline 7 & $\begin{array}{l}\text { Organizational } \\
\text { performance }\end{array}$ & 3.10 & 0.94 & $0.32^{\star * *}$ & $0.19^{\star * *}$ & $0.34^{\star \star \star}$ & $0.18^{\star \star \star}$ & $0.13^{\star *}$ & $0.29^{\star * *}$ & 1 \\
\hline
\end{tabular}

Note: 400 cases; $\mathrm{p}<0.1 ;{ }^{* *} \mathrm{p}<0.05 ;{ }^{* *} \mathrm{p}<0.01$.

To verify the multicollinearity between the variables, another guideline is to analyze the bivariate correlation, where values higher than $r=0.85$ can indicate potential problems (Kline, 2005). In this case, there were no problems of multicollinearity. From the multivariate point of view, the AMOS software allows the detection of outliers using the Mahalanobis distance, which is a statistical measure of multidimensional distance of an individual with respect to the centroid or average of observations, which were eliminated (González et al., 2006). The VIF of the dimensions of the independent variable are shown (see Table 1) in order to demonstrate that there were no collinearity problems, due to values were less than 10 (Hair et al., 1995).

In order to test the hypotheses proposed in the theoretical model, the methodology of structural equations was followed, the corresponding SEM analyzes were carried out, which will evaluate the causal relationships that are presented in the model between the dimensions of LO and organizational performance and competitiveness. The model was specified achieving the over-specification of the model, after which the model was estimated using the maximum likelihood method, prior to this the normality of the data was verified. The statistics used in SEM assume that the multivariate distribution is normal. It proceeded to analyze the normal distribution of each observed variable to determine if there is univariate normality, it was examined the asymmetry and kurtosis of each observed variable, where values between +1 and -1 will be considered excellent, while values lower than 1.60 adequate (George \& Mallery, 2001). The data fulfilled the univariate normality found in the first criterion indicated, however the multivariate normality was not fulfilled which is a condition for the use of SEM. Although the ML method is robust to slight deviations to normality, it was followed the recommendation of Medrano and Muñoz Navarro (2017), regarding the fact that in case of not having the normality assumptions or working with ordinal data it is necessary to transform the data so the bootstrapping method (Flora \& Curran, 2004 cited by Muñoz-Navarro, 2017).

The goodness indexes of adjustment of the proposed structural model were verified, obtaining good indices. According to the theory, the model has an adequate adjustment if NFI, IFI and CFI are above 0.9 and RMSEA must be below 0.05 . The indices of this study: chi 
square and degrees of freedom: Chi2 / $\mathrm{df}=1.827, \mathrm{NFI}=0.923, \mathrm{IFI}=0.964, \mathrm{CFI}=0.963$, RMSEA $=0.046$. Hence, it is considered that the model has a good fit. Subsequently, the path coefficients were examined in order to accept or reject the hypotheses. Table 4 shows the accepted hypotheses, previously mentioned.

Table 4. SEM results for hypothesis testing

\begin{tabular}{|c|l|c|l|c|c|c|}
\hline & \multicolumn{1}{|c|}{ Hypothesis } & \multicolumn{2}{|c|}{ Structural relation } & $\begin{array}{c}\text { Standardized } \\
\text { factor loading } \\
(\mathrm{t})\end{array}$ & $\mathrm{P}$ & Result \\
\hline H1 & Commitment to learning & $\rightarrow$ & $\begin{array}{l}\text { Organizational } \\
\text { performance }\end{array}$ & $0.220(3.617)$ & $* * *$ & Accepted \\
\hline H2 & Open-mindedness & $\rightarrow$ & $\begin{array}{l}\text { Organizational } \\
\text { performance }\end{array}$ & $0.490(5.136)$ & $* * *$ & Accepted \\
\hline H3 & Shared vision & $\rightarrow$ & $\begin{array}{l}\text { Organizational } \\
\text { performance }\end{array}$ & $-0.217(2.234)$ & $*$ & Rejected \\
\hline H4 & Commitment to learning & $\rightarrow$ & Competitiveness & $0.302(3.306)$ & $* * *$ & Accepted \\
\hline H5 & Open-mindedness & $\rightarrow$ & Competitiveness & $0.170(1.327)$ & & Rejected \\
\hline H6 & Shared vision & $\rightarrow$ & Competitiveness & $0.429(3.012)$ & $* *$ & Accepted \\
\hline
\end{tabular}

Notes: Model fit measures for the general model: $\mathrm{Chi}^{2} / \mathrm{df}=1.827(\mathrm{p}=0.000)$; RMSEA $=0.046$; NFI $=$ 0.923; IFI $=0.964$; TLI 0.958; CFI $=0.963$; Significance values: ${ }^{*}=\mathrm{p}<0.05{ }^{* *}=\mathrm{p}<0.01{ }^{* * *}=\mathrm{p}<0.001$.

The hypothesis test has been executed through SEM with AMOS; therefore, four of the six hypotheses has been supported. Table 4 shows the results of the proposed hypotheses for the study. Hypothesis H1: commitment to learning has a direct and positive influence on SMEs organizational performance, is accepted with a level of significance of $0.001\left(^{* * *}=p<0.001\right)$ with a standard coefficient of 0.220 and a t value of 3.617. Hypothesis H2: open-mindedness has a direct and positive influence on SMEs organizational performance, is accepted with a significance value greater than $0.001\left(^{* * *}=\mathrm{p}<0.001\right)$ has a standard coefficient of 0.490 and a t value of 5.136. Hypothesis H3: shared vision has a direct and positive influence on SMEs organizational performance, is rejected as the analysis shows a direct negative and significant impact. The Hypothesis H4: commitment to learning has a direct and positive influence on SMEs competitiveness, was accepted with a significance value of $0.001\left(^{* * *}=p<0.001\right)$ has a standard coefficient of 0.302 and a t value of 3.306. Hypothesis H5: open-mindedness has a direct and positive influence on SMEs competitiveness is rejected because, although it has a positive relationship, it does not become significant. Finally, Hypothesis H6: shared vision has a direct and positive influence on SMEs competitiveness was accepted with a significance value of $\left.0.01{ }^{* *}=p<0.01\right)$ with a standard coefficient of 0.429 and a value of $t$ of 3.012 .

\section{Discussion}

The results of the LO dimensions with competitiveness that have a positive impact are consistent with the studies of Ahmedova (2015); Allameh and Khalilakbar (2018); Ratnawati et al. (2018). The results are not consistent with previous studies such as that of Abbade (2012), in which he found a positive and significant evidence of open-mindedness, but with organiza- 
tional performance and positive evidence but not significant, between organizational commitment and shared vision with organizational performance. The results are not consistent with those of Llonch et al. (2007) they point out that LO does not have significant influence with results in relation to the objectives of the organization and in terms of its competence, considering that this implies the three dimensions of LO.

Regarding the results of LO dimensions with organizational performance, the findings are similar to the studies of Pérez et al. (2005); Cardona and Calderon (2006); Araiza et al. (2014); Gálvez et al. (2013); Calantone et al. (2002); Lita and Faisal (2018); Hussein et al. (2014); Mahmoud and Yusif (2012). Bature et al. (2018), who point out a positive influence between LO and performance without making a distinction in the impact on the different dimensions as was the case in this study. On the other hand, regarding similar studies that analyze each of dimensions, the results of this study are consistent with the findings of Perin et al. (2016), since they found a positive and significant relation between open mindedness and organizational performance. However, the findings of the dimension of the non-significant impact of shared vision are consistent with those of Llonch et al. (2007) they found a no significant but not negative influence.

An explanation of the result of the negative influence of shared vision with organizational performance can be according to the literature because although collaborators are motivated to learn, it is difficult to know what needs to be learned, an extensive problem in organizations is that because of the absence of a common direction many good ideas never be learned and implemented (Chen et al., 2017), since they are never brought into actions because no attention is paid to strategies for sharing vision (Moreno, 2009). In the literature on the subjet it is noted that when there is no clear direction towards organizational objectives, or there are different priorities among the members the results are not adequate (García et al., 2007). So, one of the explanations of the results found, may be that there is no coordination of the company's approach due to the lack of communication of the actions within the organization (Chi-hsiang, 2015).

The human factor is one of the most important elements of organizations, it is necessary for companies to establish clear guidelines to achieve integration between working groups so they can interact to achieve organizational aims. (Real et al., 2006) and The vision must be promoted to be fulfilled (Moreno, 2009). The study is similar to that of Chrisman et al. (2008) since in their study the three dimensions of LO are examined in relation to business results. They found no evidence that LO significantly impacts on performance.

\section{Conclusions}

This research was focused the role of the dimensions of learning orientation on organizational performance and competitiveness, the subject become an issue of academic relevance that can be influenced by diverse factors, such as, an emerging country with a SMEs culture. The results of the study proved four out of six hypotheses proposed in the model tested in a group of SMEs firms in Aguascalientes City, Mexico.

The findings on the relations of LO dimensions with competitiveness show that commitment to learning and shared vision are elements that positively and significantly influence 
the levels of competitiveness of SMEs, in other words, a LO committed firm, promote to challenge established routines and be open to new ideas that positively influences financial performance, reduce costs and possess better technology than competitors. Nevertheless, according to the results, open-mindedness is a dimension does not have the same relevance because although it has a positive influence on the levels of competitiveness of the company, it does not have a significant influence.

Regarding the results of LO dimensions with organizational performance, it was found that commitment to learning and open-mindedness do have a positive and significant influence but is not the case of shared vision, which has a negative and significant influence, it was tested with linear regression, transformed into averages, divides the file into high and low quartiles of shared vision. It was calculated and there were no changes, the effect of shared vision remains as not positive. According with the literature it may be that each area within the organization or each company, perceives to achieve organizational performance in a very different way.

A common direction among the team members is not possible if the objectives are unknown to them or there is discrepancy between the functional areas; it is necessary to transmit an institutional vision, to communicate it and share it as well as the objectives and strategies. Developing a strategic learning orientation implies that, the management of the company is committed to open up to new ideas and unlearn the established routines.

The findings in this study have important implications in the SMEs, because, although the LO improves performance, it is important to improve strategies in terms of developing a shared vision. It is essential to deepen in the present line of investigation, especially in examining if the results vary in different cultures and contexts, find out if LO dimensions have the same impact on performance, its impacts are differentiated or even inhibit organizational performance or competitiveness. For SMEs, the results are relevant because the same level of LO can generate higher or lower levels of organizational performance or competitiveness, depending on the contribution made by each of the dimensions of LO. The findings allow SMEs to identify for their context that it is necessary to generate actions to promote the openmindedness (as a variable of greater influence) and to commit to learning (variable in the second level of influence) in the firm if it wants to have an impact on organizational performance.

In accordance with the objectives set by the firm since it is the dimensions that influence in a more direct and significant way. On the other hand, if its objective is to influence the competition, it must focus on committing itself to learning (as a variable that has greater significant influence) and to sharing the vision (as a variable in Second place of influence). The results are relevant for the SMEs because although it is known that LO has a positive influence on business outcome variables, the impact is especially different in the form and objective of the business results that are intended, in addition to the resource constraints of different nature of the SMEs this information is necessary to focus their strategies as to which practices will give more results in what is sought. However, it is important to know if, with the increase of these elements, the levels are further improved, which would be convenient to analyze as a future line of research.

As possible future lines of research, it could be analyze the significant differences between family and non-family businesses, as well as examine whether possible significant differences 
exist with different backgrounds of company managers. That could represent significant findings regarding the influence of learning dimensions on performance variables.

\section{Acknowledgements}

We acknowledge the Autonomous University of Aguascalientes for the facilities and funding for the development of this research.

\section{Disclosure statement}

The authors declare no conflict of interest any competing financial, professional, or personal interests from other parties.

\section{References}

Abbade, E. B. (2012). O efeito da Orientação para a Aprendizagem no desempenho organizacional das empresas da região central do Rio Grande do Sul. REGE Revista de Gestão, 19(2), 241-261.

Agwu, M. E. (2018). Analysis of the impact of strategic management on the business performance of SMEs in Nigeria. Academy of Strategic Management Journal, 17(1), 1-20. https://ssrn.com/abstract=3153291

Ahmedova, S. (2015). Factors for increasing the competitiveness of small and medium- sized enterprises (SMEs) in Bulgaria. Procedia - Social and Behavioral Sciences, 195, 1104-1112. https://doi.org/10.1016/j.sbspro.2015.06.155

Akhtar, S., Arif, A., Rubi, E., \& Naveed, S. (2011). Impact of organizational learning on organizational performance: Study of higher education institutes. International Journal of Academic Research, 3(5), $327-331$.

Allameh, S. M., \& Khalilakbar, R. (2018). Exploring the antecedents of innovation performance: The roles of entrepreneurial orientation, learning orientation and organizational learning. International Journal of Business Excellence, 14(4), 470-485. https://doi.org/10.1504/ijbex.2018.090313

An, W., Zhao, X., Cao, Z., Zhang, J., \& Liu, H. (2017). How bricolage drives corporate entrepreneurship: The roles of opportunity identification and learning orientation. Journal of Product Innovation Management, 35(1), 49-65. https://doi.org/10.1111/jpim.12377

Anderson, J. C., \& Gerbing, D. W. (1988). Structural equation modeling in practice: A review and recommended two-step approach. Psychological Bulletin, 103(3), 411-423. https://doi.org/10.1037/0033-2909.103.3.411

Anning-Dorson, T. (2016). Organizational culture and leadership as mediators of service innovation and firm competitiveness: A Study of an emerging economy. International Journal of Innovation Management, 20(07), 1650064. https://doi.org/10.1142/S136391961650064X

Aragón, A., \& Sánchez, G. (2003). Orientación estratégica, características de gestión y resultados: Un estudio empírico en las PYME españolas. Información Comercial Española, Revista de Economía, 809.

Araiza, Z., de la Garza, E., \& Ramírez, M. (2014). El aprendizaje organizacional y su relación con el desempeño operativo percibido: caso de grandes empresas manufactureras de la Región Centro del estado de Coahuila. In Memorias en XIX Congreso Internacional de Investigación en Ciencias Administrativas. Durango, México.

Arbuckle, J. L. (2003). AMOS 5.0 [Computer Software]. Chicago, IL: SPSS. 
Arévalo Hernández, J. L., \& Sosa Márquez, J. H. (2017). Análisis de competitividad como herramienta para la gerencia global en las micro, pequeñas y medianas empresas (MIPYMES). Puente, 9(2), 89-96.

Argyris, C. (1976). Single-loop and double-loop models in research on decision making. Administrative Science Quarterly, 21(3), 363-375. https://doi.org/10.2307/2391848

Argyris, C., \& Schön, D. (1978). Organizational learning: A theory of action perspective. Addison-Wesley.

Baba, Y. (2015). Does learning orientation matter for nonprofit organization performance? Empirical evidence from Ghana. Leadership \& Organization Development Journal, 36(3), 234-252. https://doi.org/10.1108/LODJ-05-2013-0056

Bagozzi, R. P., \& Yi, Y. (1988). On the evaluation of structural equation models. Journal of Academy of Marketing Science, 16(1), 74-94. https://doi.org/10.1007/BF02723327

Baker, W. E., \& Sinkula, J. M. (1999). The synergistic effect of market orientation and learning orientation on organizational performance. Journal of the Academy of Marketing Science, 27(4), 411-427. https://doi.org/10.1177/0092070399274002

Barney, J., Wright, M., \& Ketchen, Jr. D. J. (2001). The resource-based view of the firm: Ten years after 1991. Journal of Management, 27(6), 625-641. https://doi.org/10.1177/014920630102700601

Bature, S. W., Sallehuddin, R. M., \& Hin, C. W. (2018). Learning orientation, access to debt finance, organizational capability and performance of small and medium enterprises: A proposed model. Academy of Accounting \& Financial Studies Journal, 22(3), 1-11.

Beneke, J., Blampied, S., Dewar, N., \& Soriano, L. (2016). The impact of market orientation and learning orientation on organisational performance: A study of small to medium-sized enterprises in Cape Town, South Africa. Journal of Research in Marketing and Entrepreneurship, 18(1), 90-108. https://doi.org/10.1108/JRME-06-2015-0033

Bentler, P. M. (1990). Comparative fit Indexes in structural models. Psychological Bulletin, 107(2), 238246. https://doi.org/10.1037/0033-2909.107.2.238

Bontis, N., Crossan, M., \& Hulland, J. (2002). Managing an organizational learning system by aligning stocks and flows. Journal of Management Studies, 39(4), 437-469. https://doi.org/10.1111/1467-6486.t01-1-00299

Broekema, W., Porth, J., Steen, T., \& Torenvlied, R. (2019). Public leaders' organizational learning orientations in the wake of a crisis and the role of public service motivation. Safety Science, 113, 200-209. https://doi.org/10.1016/j.ssci.2018.11.002

Buckley, J. P., Pass, L. C., \& Prescott, K. (1988). Measures of international competitiveness: A critical survey. Journal of Marketing Management, 4(2), 175-200. https://doi.org/10.1080/0267257X.1988.9964068

Byrne, B. (2006). Structural equation modeling with EQS: Basic concepts, applications and programming ( 2 ed.). LEA Publishers.

Byrne, B. M. (1989). A primer of LISREL: Basic applications and programming for confirmatory factor analysis analytic models. Springer, New York, NY. https://doi.org/10.1007/978-1-4613-8885-2_1

Byrne, B. M. (1998). Structural equation modeling with LISREL, PRELIS, and SIMPLIS: basic concepts, applications, and programming. Psychology Press.

Calantone, R. J., Cavusgil, S. T., \& Zhao, Y. (2002). Learning orientation, firm innovation capability and firm performance. Industrial Marketing Management, 31(6), 515-524. https://doi.org/10.1016/S0019-8501(01)00203-6

Camisón, C. (1997). La competitividad de la PYME industrial Española: estrategia y competencias distintivas. Civitas, Madrid. 
Camisón, C., \& Puig, A. (2014). Innovaciones y prácticas organizativas como determinantes de la competitividad. Economía Industrial, 391, 59-70.

Cardona, J., \& Calderón, G. (2006). El impacto del aprendizaje en el rendimiento de las organizaciones. Cuadernos de Administración, 19(32), 11-43.

Chabowski, B. R., \& Mena, J. A. (2017). A review of global competitiveness research: Past advances and future directions. Journal of International Marketing, 25(4), 1-24. https://doi.org/10.1509/jim.16.0053

Chen, C. Y., Huang, H. H., \& Wey, S. C. (2017). The mediating roles of differentiation strategy and learning orientation in the relationship between entrepreneurial orientation and firm performance. Corporate Management Review, 37(1), 1-40.

Chenhall, R. H., \& Langfield-Smith, K. (2007). Multiple perspectives of performance measures. European Management Journal, 25(4), 266-282. https://doi.org/10.1016/j.emj.2007.06.001

Chi-hsiang, C. (2015). Effects of shared vision and integrations on entrepreneurial performance. Chinese Management Studies, 9(2), 150-175. https://doi.org/10.1108/CMS-04-2013-0057

Chrisman, J. J., Steier, L. P., \& Chua, J. H. (2008). Toward a theoretical basis for understanding the dynamics of strategic performance in family firms. Entrepreneurship Theory and Practice, 32(6), 935-947. https://doi.org/10.1111/j.1540-6520.2008.00264.x

Combs, J. G., Crook, T. R., \& Shook, C. L. (2005). The dimensionality of organizational performance and its implications for strategic management research. In D. Ketchen \& D. Bergh (Eds.), Research methodology in strategic management. Elsevier.

Crossan, M. M., Lane, H. W., \& White, R. E. (1999). An organizational learning framework: From intuition to institution. Academy of Management Review, 24(3), 522-537. https://doi.org/10.5465/amr.1999.2202135

Dávila, A., \& Elvira, M. M. (2010). La evaluación del rendimiento en empresas intensivas en conocimiento: Un caso de estudio. Universia Business Review, 27, 124-141.

De Brito, R. P., \& de Oliveira, L. B. (2016). The relationship between human resource management and organizational performance. Brazilian Business Review, 13(3), 90-110. https://doi.org/10.15728/bbr.2016.13.3.5

Del Río, C. J., \& Santisteban, R. D. F. (2011). Perspectivas del aprendizaje organizacional como catalizador de escenarios competitivos. Revista Ciencias Estratégicas, 19(26), 247-266.

Dess, G. G., \& Robinson, R. B. Jr. (1984). Measuring organizational performance in the absence of objective measures: the case of privately held and conglomerate business unit. Strategic Management Journal, 5(3), 265-273. https://doi.org/10.1002/smj.4250050306

Dragnić, D. (2014). Impact of internal and external factors on the performance of fast-growing small and medium businesses. Management-Journal of Contemporary Management Issues, 19(1), 119-159.

Dutta, D. K., Gupta, V. K., \& Chen, X. (2016). A tale of three strategic orientations: A moderatedmediation framework of the impact of entrepreneurial orientation, market orientation, and learning orientation on firm performance. Journal of Enterprising Culture, 24(3), 313-348. https://doi.org/10.1142/S0218495816500126

Ellinger, A. E., Chen, H., Tian, Y., \& Armstrong, C. (2015). Learning orientation, integration, and supply chain risk management in Chinese manufacturing firms. International Journal of Logistics Research and Applications, 18(6), 476-493. https://doi.org/10.1080/13675567.2015.1005008

Flora, D. B., \& Curran, P. J. (2004). An empirical evaluation of alternative methods of estimation for confirmatory factor analysis with ordinal data. Psychological Methods, 9(4), 466-491. https://doi.org/10.1037/1082-989X.9.4.466

Fornell, C. (1985). A second generation of multivariate analysis: Classification of methods and implications for marketing research (Working paper No. 414). The University of Michigan. 
Fornell, C., \& Larcker, D. (1981). Evaluating structural equation models with unobservable variables and measurement error. Journal of Marketing Research, 18(1), 39--50. https://doi.org/10.1177/002224378101800104

Gálvez, A. E. J., Contreras, P. F. D., \& Maldonado, G. G. (2013). La orientación al aprendizaje organizacional y su efecto en el desempeño de las MIPYMES colombianas. FAEDPYME International Review, 2(3), 49-59. https://doi.org/10.15558/fir.v2i3.29

Gálvez Albarracín, E. J., \& Pérez de Lema, D. G. (2011). Cultura organizacional y rendimiento de las Mipymes de mediana y alta tecnología: un estudio empírico en Cali, Colombia. Cuadernos de Administración, 24(42), 125-145.

García, M. V. J., Jiménez, B. M., \& Lloréns, M. F. J. (2011). Influencia del nivel de aprendizaje en la innovación y desempeño organizativo: factores impulsores del aprendizaje. Revista Europea de Dirección y Economía de la Empresa, 20(1), 161-186.

García, V. J., Romerosa, M. M. y Llórens, F. J. (2007). Liderazgo transformacional: Influencia en la visión compartida, aprendizaje, innovación y resultado organizativo. Revista Europea de Dirección y Economía de la Empresa, 16(4), 25-46.

Garrido, M. J., \& Camarero, C. (2010). Assessing the impact of organizational learning and innovation on performance in cultural organizations. International Journal of Nonprofit and Voluntary Sector Marketing, 15(3), 215-232. https://doi.org/10.1002/nvsm.384

George, D., \& Mallery, P. (2001). SPSS for windows Step by Step A simple guide and reference, 10.0 update ( $3^{\text {rd }}$ ed.). Allyn and Bacon. https://lib.ugent.be/catalog/rug01:000685813

Geringer, J. M., \& Herbert, L. (1991). Measuring performance in international joint ventures. Journal of International Business Studies, 22(2), 249-263. https://doi.org/10.1057/palgrave.jibs.8490302

Giménez, J., Madrid-Guijarro, A., \& Duréndez, A. (2019). Competitive capabilities for the innovation and performance of Spanish construction companies. Sustainability, 11(19), 1-24. https://doi.org/10.3390/su11195475

Gónzalez, N., Abad, J., \& Lévy, J. P. (2006). Normalidad y otros supuestos en análisis de covarianzas. The McG-Hill Companies, Inc., New York, NY, USA.

Gupta, V. K., \& Wales, W. J. (2017). Assessing organisational performance within entrepreneurial orientation research: Where have we been and where can we go from here? The Journal of Entrepreneurship, 26(1), 51-76. https://doi.org/10.1177/0971355716677389

Hair, J. F., Anderson, R. E., Tatham, R. L., \& Black, W. C. (1995). Multivariate data analysis with readings. Prentice-Hall.

Hakala, H. (2011). Strategic orientations in management literature: Three approaches to understanding the interaction between market, technology, entrepreneurial and learning orientations. International Journal of Management Reviews, 13(2), 199-217. https://doi.org/10.1111/j.1468-2370.2010.00292.x

Hayati, N., \& Rukhviyanti, N. (2016). Leadership capability for market orientation and learning orientation and its impact on the institution performance and competitiveness: A case of STIE Indonesia. Procedia-Social and Behavioral Sciences, 219, 291-298. https://doi.org/10.1016/j.sbspro.2016.04.03

Homaid, A. A., Minai, M. S., \& Al-Ansi, A. A. (2018). The effect of market and entrepreneurial orientation on the performance of microfinance institutions: The mediating role of learning orientation in the context of Yemen. Journal of Business and Retail Management Research, 12(3). https://doi.org/10.24052/JBRMR/V12IS03/ART-11

Hooi, L. W., \& Ngui, K. S. (2014). Enhancing organizational performance of Malaysian SMEs: The role of HRM and organizational learning capability. International Journal of Manpower, 35(7), 973-995. https://doi.org/10.1108/IJM-04-2012-0059

Huber, G. P. (1991). Organizational learning: The contributing processes and the literatures. Organization Science, 2(1), 88-115. https://doi.org/10.1287/orsc.2.1.88 
Hurley, R. F., \& Hult, G. T. M. (1998). Innovation, market orientation and organizational learning: An integration and empirical examination. Journal of Marketing, 62(3), 42-54. https://doi.org/10.1177/002224299806200303

Hussein, N., Mohamad, A., Noordin, F., \& Ishak, N. A. (2014). Learning organization and its effect on organizational performance and organizational innovativeness: A proposed framework for Malaysian Public Institutions of Higher Education. Procedia-Social and Behavioral Sciences, 130, 299-304. https://doi.org/10.1016/j.sbspro.2014.04.035

IMCO. (2016). Los estados más y menos competitivos en México. https://imco.org.mx/competitividad/ los-estados-mas-y-menos-competitivos-en-mexico/

INEGI. (2016a). Directorio Estadístico Nacional de Unidades Económicas. http://www.beta.inegi.org. $\mathrm{mx} / \mathrm{app} / \mathrm{mapa} /$ denue/

INEGI. (2016b). Estadísticas detalladas sobre las micro, pequeñas y medianas empresas del país. http:// www.inegi.org.mx/saladeprensa/boletines/2016/especiales/especiales2016_07_02.pdf

Iyer, K. N., Srivastava, P., \& Srinivasan, M. (2019). Performance implications of lean in supply chains: Exploring the role of learning orientation and relational resources. International Journal of Production Economics, 216, 94-104. https://doi.org/10.1016/j.ijpe.2019.04.012

Jerez, P. (2001). Gestión de recursos humanos y aprendizaje: incidencia e implicaciones (Tesis doctoral no publicada). Universidad de Almería, España.

Jöreskog, K. G., \& Sörbom, D. (1986). LISREL VI: Analysis of linear structural relations by maximum likelihood, instrumental variables and square methods. Moorsville, I. N. Scientific Software.

Kasim, A., Ekinci, Y., Altinay, L., \& Hussain, K. (2018). Impact of market orientation, organizational learning and market conditions on small and medium-size hospitality enterprises. Journal of Hospitality Marketing \& Management, 27(7), 855-875.

https://doi.org/10.1080/19368623.2018.1438955

Kerfai, N., \& Bejar Ghadhab, B. (2016). Performance concept through a service-dominant logic in Tunisian manufacturing companies. International Journal of Innovation, 4(2), 86-96. https://doi.org/10.5585/iji.v4i2.88

Kline, R. B. (2005). Principles and practice of structural equation modeling. Guilford.

Lall, S., Albaladejo, M., \& Mesquita, M. (2005). La Competitividad Industrial de América Latina y el Desafío de la Globalización. BID.

Liao, S., Chen, C. C., Hu, D., Chung, Y. C., \& Liu, C. L. (2017). Assessing the influence of leadership style, organizational learning and organizational innovation. Leadership \& Organization Development Journal, 38(5), 590-609. https://doi.org/10.1108/LODJ-11-2015-0261

Lita, R. P., Meuthia, \& Faisal, R. F. (2018). SME's performance of creative industries supporting tourism in Indonesia: Market orientation, learning orientation and organizational innovativeness as determinants. Academy of Marketing Studies Journal, 22(1). https://doi.org/10.20885/jsb.vol22.iss1.art3

Llonch, J., López, M., \& Eusebio, R. (2007). Orientación al Aprendizaje, Orientación al Mercado, Resultados y el Efecto Moderador de la Procedencia Funcional del Director General. Cuadernos de Economía y Dirección de la Empresa, 10(33), 63-94. https://doi.org/10.1016/S1138-5758(07)70098-1

Mahmoud, M. A., \& Yusif, B. (2012), Market orientation, learning orientation, and the performance of non-profit organizations (NPOs). International Journal of Productivity and Performance Management, 61(6), 624-652. https://doi.org/10.1108/17410401211249193

Mahmoud, M. A., Blankson, C., Owusu-Frimpong, N., Nwankwo, S., \& Trang, T. P. (2016). Market orientation, learning orientation and business performance: The mediating role of innovation. International Journal of Bank Marketing, 34(5), 623-648. https://doi.org/10.1108/IJBM-04-2015-0057

Maldonado, G. G. (2008). El impacto de la flexibilidad de la logística y la capacidad directiva en la Competitividad de la industria del mueble en España (Tesis Doctoral). Universidad de Valencia, Facultad de Economía, Departamento de Comercialización e Investigación de Mercado. 
Maldonado, G. G., Sánchez, G. J., Gaytán, C. J., \& García, R. R. (2012). Measuring the competitiveness level in furniture SMEs of Spain. International Journal of Economics and Management Sciences, 1(11), 9-19.

Martínez, M. D. C. (2004). Orientación a Mercado. Un modelo desde la perspectiva de aprendizaje organizacional. Universidad Autónoma de Aguascalientes, México.

Medrano, L. A., \& Múñoz-Navarro, R. (2017). Aproximación conceptual y práctica a los modelos de ecuaciones estructurales. Revista digital de investigación en docencia universitaria, 11(1), 219-239. https://doi.org/10.19083/ridu.11.486

Moreno, L. Á. (2009). Comunicación Efectiva para el Logro de una Visión Compartida. CULCyT, 6(32).

Parra, D. E. (2006). Liderazgo y rendimiento de la gerencia intermedia bajo la perspectiva de los objetivos balanceados. Revista Negotium, 4, 50-83.

Pearce, J. A., Robbins, D. K., \& Robinson, Jr. R. B. (1987). The impact of grand strategy and planning formality on financial performance. Strategic Management Journal, 8(2), 125-134.

https://doi.org/10.1002/smj.4250080204

Pérez, M. D. P. P., Gutiérrez, P. I. R., \& Agudo, J. C. (2019). El papel de la orientación al aprendizaje en la innovación y el desempeño: Un estudio en micro, pequeñas y medianas empresas en San Luis Potosí (México). Contaduría y administración, 64(1), 10. https://doi.org/10.22201/fca.24488410e.2018.1676

Pérez, S., Montes, J. M., \& Vázquez, C. (2005). Human resource practices, organizational learning and business performance. Human Resource Development International, 8(2), 147-164. https://doi.org/10.1080/13678860500100103

Perin, M. G., Sampaio, C. H., Jiménez-Jiménez, D., \& Cegarra-Navarro, J. G. (2016). Network effects on radical innovation and financial performance: An open-mindedness approach. BAR-Brazilian Administration Review, 13(4). https://doi.org/10.1590/1807-7692bar2016160057

Peterson, P. P. (1994). Financial management and analysis. McGraw-Hill.

Potnuru, R. K. G., Sahoo, C. K., \& Sharma, R. (2019). Team building, employee empowerment and employee competencies: Moderating role of organizational learning culture. European Journal of Training and Development, 43(1/2), 39-60. https://doi.org/10.1108/EJTD-08-2018-0086

Ratnawati, Soetjipto, B. E., Murwani, F. D., \& Wahyono, H. (2018). The role of SMEs' innovation and learning orientation in mediating the effect of CSR programme on SMEs' performance and competitive advantage. Global Business Review, 19(3_suppl), S21-S38.

https://doi.org/10.1177/0972150918757842

Real Fernández, J. C., Leal Millán, A., \& Roldán Salgueiro, J. L. (2006). La Problemática En La Medición Del Aprendizaje Organizativo: Una Revisión. Investigaciones Europeas de Dirección y Economía de la Empresa (IEDEE), 12(1), 153-166.

Real, J. C., Roldán, J. L., \& Leal, A. (2014). From entrepreneurial orientation and learning orientation to business performance: Analyzing the mediating role of organizational learning and the moderating effects of organizational size. British Journal of Management, 25(2), 186-208. https://doi.org/10.1111/j.1467-8551.2012.00848.x

Rehman, S., Mohamed, R., \& Ayoup, H. (2019). The mediating role of organizational capabilities between organizational performance and its determinants. Journal Global Entrepreneurship Research, 9(1), 30. https://doi.org/10.1186/s40497-019-0155-5

Richard, P. J., Devinney, T. M., Yip, G. S., \& Johnson, G. (2009). Measuring organizational performance: Towards methodological best practice. Journal of Management, 35(3), 718-804. https://doi.org/10.1177/0149206308330560

Rubio, A., \& Aragón, A. (2006). Competitividad y recursos estratégicos en la PYME. Revista de Empresa, 17, 32-47. 
Rubio, A. M. (2004). Factores explicativos del éxito competitivo en la pyme (Doctoral dissertation). Universidad de Murcia.

Saavedra García, M. L., Milla Toro, S. O., \& Tapia Sánchez, B. (2013). Determinación de la competitividad de la PYME en el nivel micro: El caso de del Distrito Federal, México. FAEDPYME International Review, 2(4), 38-52. https://doi.org/10.15558/fir.v2i4.38

Salunke, S., Weerawardena, J., \& McColl-Kennedy, J. R. (2019). The central role of knowledge integration capability in service innovation-based competitive strategy. Industrial Marketing Management, 76, 144-156. https://doi.org/10.1016/j.indmarman.2018.07.004

Sawaean, F., \& Ali, K. (2020). The impact of entrepreneurial leadership and learning orientation on organizational performance of SMEs: The mediating role of innovation capacity. Management Science Letters, 10(2) 369-380. https://doi.org/10.5267/j.msl.2019.8.033

Secretaria de Economía. (2016). Información Económica y Estatal. https://www.gob.mx/cms/uploads/ attachment/file/194462/aguascalientes_2017_02.pdf

Senge, P. M. (1990). The fifth discipline: The art and practice of the learning organization. Doubleday.

Shad, M. K., Lai, F. W., Fatt, C. L., Klemeš, J. J., \& Bokhari, A. (2019). Integrating sustainability reporting into enterprise risk management and its relationship with business performance: A conceptual framework. Journal of Cleaner Production, 208, 415-425. https://doi.org/10.1016/j.jclepro.2018.10.120

Sinkula, J. M., Baker, W. E., \& Noordewier, T. (1997). A framework for market-based organizational learning: Linking values, knowledge, and behavior. Journal of the Academy of Marketing Science, 25(4), 305-318. https://doi.org/10.1177/0092070397254003

Slater, S., \& Narver, J. (1995). Market orientation and the learning organization. Journal of Marketing, 59(3), 63-75. https://doi.org/10.1177/002224299505900306

Slater, S. F., \& Narver, J. C. (1994). Does competitive environment moderate the market orientationperformance relationship? Journal of Marketing, 58(1), 46-55.

https://doi.org/10.1177/002224299405800104

Stankard, M. F. (2002). Management systems and organizational performance: The search for excellence beyond ISO9000. Greenwood Publishing Group.

Tajeddini, K. (2016). Analyzing the influence of learning orientation and innovativeness on performance of public organizations: The case of Iran. Journal of Management Development, 35(2), 134153. https://doi.org/10.1108/JMD-03-2015-0033

Vargas, M. I. R. (2015). Determinant factors for small business to achieve innovation, high performance and competitiveness: Organizational learning and leadership style. Procedia-Social and Behavioural Sciences, 169, 43-52. https://doi.org/10.1016/j.sbspro.2015.01.284

Vasconcelos, V., Silveira, A., \& Bizarrias, F. (2016). The relations between entrepreneurial orientation, organizational learning and organizational performance of small enterprises. International Journal of Professional Business Review, 1(2), 1-14.

Venkatraman, N., \& Ramanujam, V. (1986). Measurement of business performance in strategy research: A comparison of approaches. Academy of Management Review, 11(4), 801-814. https://doi.org/10.5465/amr.1986.4283976

Von Krogh, G., Nonaka, I., \& Rechsteiner, L. (2012). Leadership in organizational knowledge creation: A review and framework. Journal of Management Studies, 49(1), 240-277. https://doi.org/10.1111/j.1467-6486.2010.00978.x

Wernerfelt, B. (1984). A resource-based view of the firm. Strategic Management Journal, 5(2), 171-180. https://doi.org/10.1002/smj.4250050207 
Wolff, J. A., Pett, T. L., \& Ring, J. K. (2015). Small firm growth as a function of both learning orientation and entrepreneurial orientation: An empirical analysis. International Journal of Entrepreneurial Behavior \& Research, 21(5), 709-730. https://doi.org/10.1108/IJEBR-12-2014-0221

World Economic Forum. (2018). The global competitiveness report 2017-2018. http://www3.weforum. org/docs/GCR20172018/05FullReport/TheGlobalCompetitivenessReport2017\%E2\%80\%932018. pdf

Yang, J. J., \& Huang, S. Z. (2018). A study on the effects of supply chain relationship quality on firm performance-under the aspect of shared vision. Journal of Interdisciplinary Mathematics, 21(2), 419-430. https://doi.org/10.1080/09720502.2017.1420571

Yazfanfar, D. (2013). Profitability determinants among micro firms: evidence from Swedish data. International Journal of Managerial, 9(2), 150-160. https://doi.org/10.1108/17439131311307565 